\title{
PENGUKURAN KINERJA RANTAI PASOK KOMODITAS IKAN BANDENG BEKU DENGAN PENDEKATAN SCOR
}

\section{PERFORMANCE MEASUREMENT OF SUPPLY CHAIN COMMODITIES BANDENG FROZEN USING SCOR APPROACH}

\author{
A Ginantaka1a \\ ${ }^{1}$ Program Studi Teknologi Industri Pertanian, Fakultas Ilmu Pangan Halal, Universitas Djuanda Bogor \\ Jl. Tol Ciawi No. 1, Kotak Pos 35 Ciawi, Bogor 16720. \\ a Korespondensi: Aditia Ginantaka, E-mail: aditia.ginantaka@unida.ac.id \\ (Diterima: 28-07-2017; Ditelaah: 29-07-2017; Disetujui: 20-10-2017)
}

\begin{abstract}
Cheap, quality and fast products are every customer's expectation. A good supply chain mechanism can ensure the smooth flow of agricultural and fishery commodities from farming units to consumer tables. Fishing aquaculture sectors such as milkfish ponds are the contributors of Indonesian fishery exports. Supply chain management system is done in order to satisfy the final consumer, so as to maintain endurance and improve the competitiveness of frozen milkfish products. This study aims to measure the performance of frozen milkfish supply chain through SCOR approach by using performance metrics that have been established in the supply chain council. Besides, this research also aims to perform benchmarking based on company improvement targets. Based on the measurement results, it is known that the performance of supply chain of frozen milkfish products is still $70,36 \%$, and most of them are still below the benchmark value. Performance improvements are made by defining in detail every process on level 1 to a series of processes at level 3 .
\end{abstract}

Keywords: milkfish, performance, fishery, supply chain.

\begin{abstract}
ABSTRAK
Produk murah, berkualitas dan cepat merupakan harapan setiap konsumen. Mekanisme rantai pasok yang baik dapat menjamin kelancaran arus komoditas pertanian dan perikanan sejak dari unit budidaya (farm) hingga meja makan (table) konsumen. Sektor perikanan budidaya tambak seperti tambak ikan bandeng merupakan penyumbang ekspor perikanan indonesia. Pengelolaan sistem rantai pasok dilakukan dalam rangka memuaskan konsumen akhir, sehingga mampu menjaga daya tahan serta meningkatkan daya saing produk ikan bandeng beku. Penelitian ini bertujuan untuk melakukan pengukuran kinerja rantai pasok ikan bandeng beku melalui pendekatan SCOR dengan menggunakan metrik kinerja yang telah ditetapkan dalam supply chain council. Disamping itu penelitian ini juga bertujuan untuk melakukan benchmarking berdasarkan target perbaikan perusahaan. Berdasarkan hasil pengukuran, diketahui bahwa kinerja rantai pasok produk bandeng beku saat ini masih sebesar 70, $36 \%$, dan sebagian besar masih berada dibawah nilai benchmark. Perbaikan kinerja dilakukan dengan mendefinisikan secara mendetail setiap proses pada level 1 hingga rangkaian proses pada level 3.
\end{abstract}

Kata kunci: bandeng, kinerja, perikanan, rantai pasok.

Ginantaka A. 2017. Pengukuran Kinerja Rantai Pasok Komoditas Ikan Bandeng Beku dengan Pendekatan SCOR. Jurnal Pertanian 8(2): 91-97. 


\section{PENDAHULUAN}

Kondisi geografis Indonesia dengan luas wilayah yang didominasi oleh lautan memberikan peluang besar bagi pengembangan potensi perikanan. Data FAO tahun 2010 menunjukkan volume produksi perikanan tangkap Indonesia menempati posisi nomor 3 dunia setelah China dan Peru, sedangkan hasil budidaya menempati posisi 4 besar [1]. Produksi ikan nasional terus meningkat hingga tahun 2012 dengan total produksi mencapai 15.548 .038 ton dengan pertumbuhan rata-rata sebesar $12,19 \%$ [2]. Berdasarkan konvensi hukum laut PBB ke tiga, United Nation Convention on the Law of the Sea 1982 (UNCLOS 1982), total luas wilayah laut Indonesia mencapai 5,9 juta $\mathrm{Km}^{2}$ sementara luas daratan hanya sekitar 1,9 juta $\mathrm{Km}^{2}$ [1].

Luasnya wilayah perairan Indonesia menunjukan bahwa potensi sumberdaya alam perairan Indonesia begitu melimpah dan dapat menjadi salah satu pendukung pertumbuhan ekonomi nasional. Perkembangan ekspor produk perikanan indonesai hingga tahun 2012 pun terus mengalami peningkatan. Produk perikanan yang menjadi unggulan ekspor diantaranya udang dan ikan tongkol-tuna dengan volume berturut-turut mencapai 122.900 ton dan 105.800 ton [2]. Peningkatan volume ekspor dalam tiga tahun terakhir menunjukan adanya sinyal positif bagi pengembangan ekspor produk perikanan nasional.

Salah satu sektor perikanan yang berkontribusi dalam perkembangan perikanan adalah sektor perikanan budidaya tambak, misalnya tambak ikan bandeng. Untuk segmentasi pasar menengah keatas ikan bandeng diproduksi dalam bentuk beku dengan pelanggan berupa supermarket atau restoran. Produk murah, berkualitas dan cepat merupakan harapan setiap konsumen. Ditambah lagi dengan adanya perdagangan bebas tingkat ASEAN dalam bentuk asean economic community (AEC) di tahun 2015, menuntut manajemen rantai pasok perikanan terus ditingkatkan.

Pengelolaan sistem rantai pasok dilakukan dalam rangka memuaskan konsumen akhir, sehingga mampu menjaga daya tahan serta meningkatkan daya saing produk ikan bandeng beku. Untuk mencapai hal tersebut perlu dukungan semua entitas rantai pasok, mulai dari pemasok yang mengolah bahan baku menjadi produk jadi, perusahaan transportasi yang mengirimkan bahan baku dari pemasok ke pabrik, serta jaringan distribusi yang akan menyampaikan produk ke tangan konsumen. Salah satu upaya untuk meningkatkan manajemen rantai pasok adalah dengan mengevaluasi kinerja rantai pasok sehingga dapat diketahui pada tahap mana dalam proses pemenuhan kebutuhan konsumen yang mengalami masalah. Pengukuran kinerja rantai pasok ikan bandeng beku dapat dilakukan melalui pendekatan SCOR dengan menggunakan metrik kinerja yang telah ditetapkan dalam supply chain council. Dari pengukuran kinerja rantai pasokan dengan menggunakan SCOR Model, diharapkan perusahaan mampu mengetahui seberapa besar kinerja perusahaan sampai saat ini dibandingkan dengan pesaingnya. Selain itu, perusahaan juga diharapkan mampu mengetahui letak kelemahan dalam bersaing di perindustrian [3].

Tujuan dari paper ini ada dua. Pertama, mengidentiifikasi metrik level 1 yang dapat menjadi alat ukur kinerja rantai pasok ikan bandeng beku. Kedua yaitu, mengukur kinerja dan melakukan benchmarking berdasarkan target perbaikan perusahaan.

\section{MATERI DAN METODE}

\section{Materi}

\section{Rantai Pasok Perikanan}

Sistem rantai pasok perikanan meliputi internal perusahaan dengan unit penanganan produk yang merepresentasikan sistem rantai pasok produk, diantaranya meliputi unit budidaya, unit pengolahan, unit cold storage dan unit pengguna akhir (end user) yang berupa restoran dan unit retail. Selain diperoleh dari unit budidaya, bahan baku ikan bandeng pada sektor hulu, juga diperoleh dari 
mitra tani. Ruang lingkup rantai pasok ikan bandeng ditunjukan pada Gambar 1.

scope Diagram

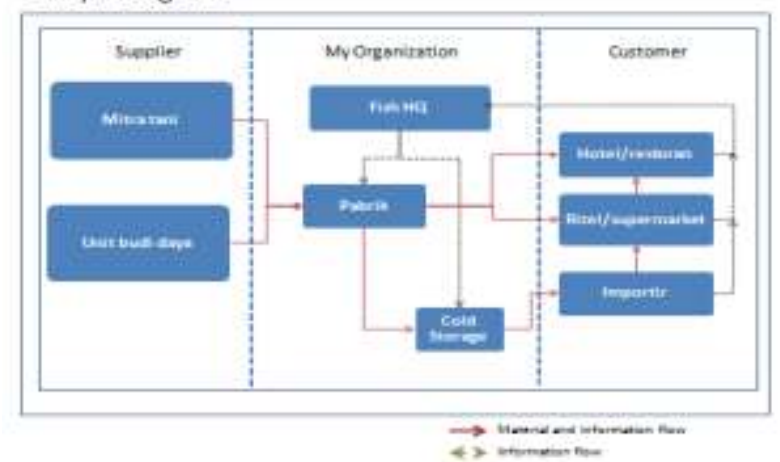

Proses produksi ikan bandeng beku (Gambar 2) diawali dari proses pemanenan ikan dan berakhir pada saat produk ikan bandeng beku sampai di rumah konsumen. Tahapan proses setelah pemanenan merupakan titik kritis proses keamanan pangan produk ikan bandeng beku. Prosedur spesifik untuk mengetahui ada atau tidaknya bahan kontaminasi mengikuti syarat mutu ikan beku seperti yang tercantum dalam dokumen SNI 01-4110.1-2006.

Gambar 1 Ruang lingkup sistem rantai pasok ikan Bandeng beku [4]

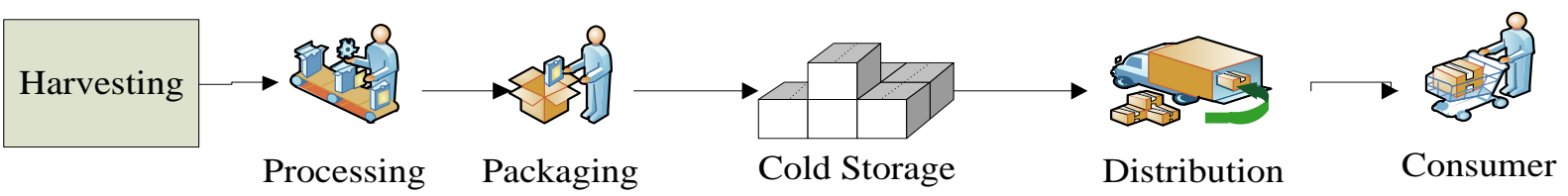

Gambar 2 Proses produksi ikan bandeng beku

\section{SCOR (Supply Chain Operation Reference)}

SCOR adalah suatu model referensi proses yang dikembangkan oleh dewan rantai pasokan (supply chain council) sebagai alat diagnosa manajemen rantai pasok. ruang lingkup SCOR mencakup dari pemasoknya pemasok hingga ke konsumennya konsumen. Pendekatan SCOR menyajikan ukuran kuantitatif sebagai kriteria pengukuran yang disebut dengan metrik. Umumnya perusahaan yang menerapkan pendekatan SCOR menggunakan kartu SCOR yang disertai metrik-metrik penilaiannnya. Metrik SCOR mengukur setiap metrik yang merepresentasikan kinerja internal dan eksternal perusahaan.

Supply chain council telah menetapkan definisi tertentu yang dapat memudahkan sebuah perusahaan untuk memodelkan dan mendeskripsikan proses rantai pasok yang terjadi. Proses rantai pasokan didefinisikan dalam lima proses yang terintegrasi meliputi perencanaan (plan), pengadaan (source), produksi (make), distribusi (deliver) dan pengembalian (return). Kelima proses tersebut merupakan level 1 dalam model SCOR. Penjabaran setiap proses dapat dikelompokan berdasarkan 3 kategori proses rantai pasok yang terjadi dan merupakan level
2 dari model SCOR. Diantaranya, (1) make-tostock, (2) make-to-order dan (3) make-toassemble.

Tabel 1 Indikator kinerja rantai pasok

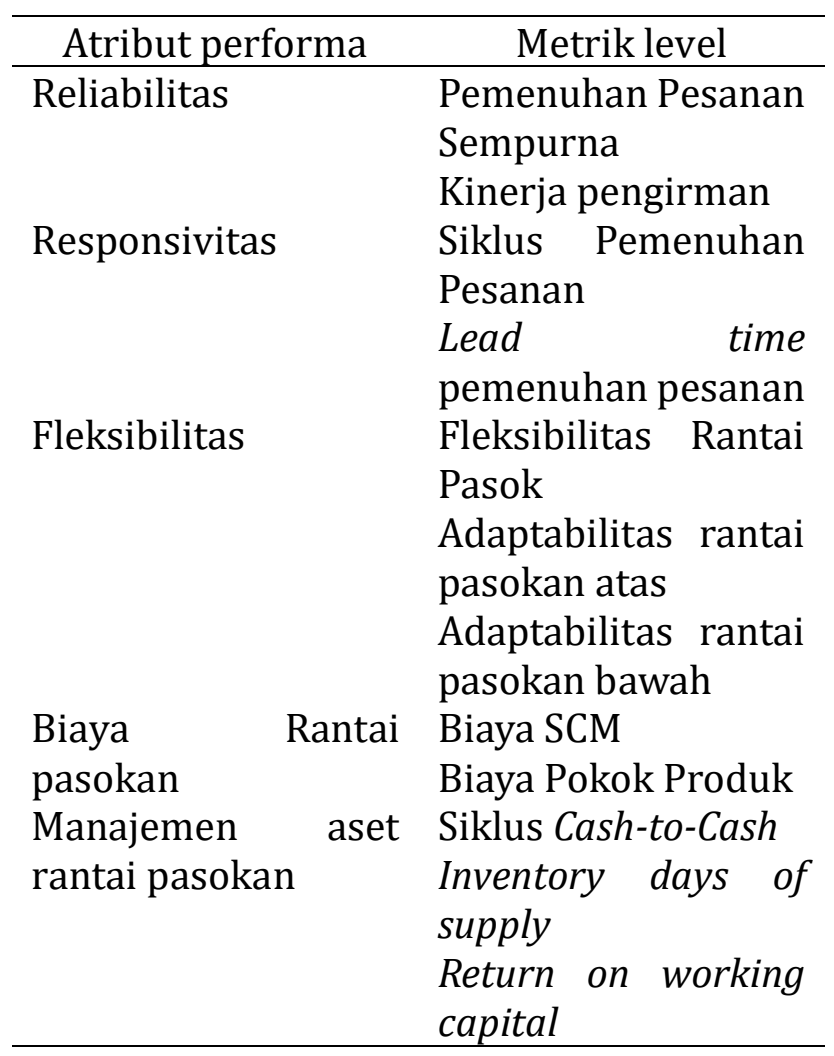

Penjabaran lebih detail dari level 2 merupakan rangkaian urutan proses yang 
terjadi disetiap level 2, seperti penjadwalan pengiriman, penerimaan material dan verifikasi material, yang merupakan level teknis dari proses manajemen rantai pasoknya.

Setiap level menggambarkan proses yang terjadi dalam rangka pelaksanaan manajemen rantai pasok. pengukuran performa dari proses rantai pasok dilakukan dengan menggunakan kriteria-kriteria yang juga telah ditetapkan dalam model SCOR. Kriteria tersebut disebut sebagai atribut performa, yang memiliki satu atau lebih metrik level 1. Metrik level ini yang menjadi indikator pengukuran performa rantai pasok, seperti yang tercantum pad Tabel 1 .

\section{Metode}

Paper ini menggunakan analisis deskriptif untuk mendeskripsikan permasalahan yang terjadi. Berdasarkan metrik level 1 pada pengukuran kinerja diidentifikasi indikator yang mempengaruhi kinerja rantai pasok ikan bandeng beku. Nilai dari setiap indikator menggunakan data hipotetikal, dengan benchmark berdasarkan target perusahaan. Setiap atribut pada metrik level 1 dihitung bobotnya dengan teknik AHP. Pembobotan ini digunakan untuk mengkonversi nilai keseluruhan atribut dalam bentuk persentase. Proses perbandingan berpasangan dari metode AHP (analytical hierarchy process) dilakukan dengan menggunakan judgement penulis dengan mempertimbangkan literatur yang ada.

\section{HASIL DAN PEMBAHASAN}

Banyaknya metrik dan tingkatan metrik yang digunakan disesuaikan dengan jenis dan banyaknya proses serta tingkatan proses rantai pasokan yang diterapkan oleh perusahaan. Berdasarkan hasil identifikasi metrik level 1 pada rantai pasok produk ikan bandeng beku, diperoleh beberapa atribut performa dan metrik level 1 yang sesuai. Hasil identifikasi metrik level 1 ditunjukan pada Tabel 2.

Tabel 2 Metrik level 1 yang mempengaruhi kinerja rantai pasok ikan bandeng beku

\begin{tabular}{|c|c|c|c|c|c|}
\hline \multirow{3}{*}{ Metrik Level 1} & \multicolumn{5}{|c|}{ Atribut Kinerja } \\
\hline & \multicolumn{3}{|c|}{ Eksternal (Customer) } & \multicolumn{2}{|c|}{ Internal } \\
\hline & Reliabilitas & Responsivitas & Fleksibilitas & Biaya & Aset \\
\hline Pemenuhan Pesanan & & & & & \\
\hline Sempurna (PP) & $X$ & & & & \\
\hline Kinerja pengirman (KP) & $\mathrm{x}$ & & & & \\
\hline $\begin{array}{l}\text { Siklus Pemenuhan } \\
\text { Pesanan (SPP) }\end{array}$ & & $\mathrm{x}$ & & & \\
\hline $\begin{array}{l}\text { Lead time pemenuhan } \\
\text { pesanan (LPP) }\end{array}$ & & $\mathrm{x}$ & & & \\
\hline $\begin{array}{l}\text { Fleksibilitas } \quad \text { Rantai } \\
\text { Pasok (FP) }\end{array}$ & & & $\mathrm{x}$ & & \\
\hline Biaya SCM (BSCM) & & & & $x$ & \\
\hline $\begin{array}{lll}\text { Biaya } & \text { Pokok } & \text { Produk } \\
\text { (BPP) } & & \end{array}$ & & & & $\mathrm{x}$ & \\
\hline $\begin{array}{l}\text { Siklus Cash-to-Cash } \\
\text { (CTC) }\end{array}$ & & & & & $\mathrm{X}$ \\
\hline $\begin{array}{l}\text { Inventory days of supply } \\
\text { (PH) }\end{array}$ & & & & & $\mathrm{x}$ \\
\hline
\end{tabular}

Model proses yang digunakan dalam rantai pasok ikan bandeng beku, juga disesuaikan dengan bisnis proses yang terjadi [6] sehingga diperoleh atribut model SCOR untuk setiap level adalah sebagai berikut. 
1. Level 1 (Proses Bisnis)

Perencanaan (PLAN), Pengadaan (SOURCE), Budidaya (MAKE), Pengolahan (PROCESS), Pengiriman (DELIVER)

2. Level 2 (Faktor Kinerja)

Nilai tambah, Kualitas, Risiko

3. Level 3 (Atribut Kinerja)

Reliability, Responsiveness, Flexibility, Cost, Aset.

Untuk memperoleh bobot dari metrik level 1 pada pengukuran kinerja, maka perlu ditentukan juga bobot untuk setiap level pada atribut model SCOR dengan menggunakan AHP [6]. Analisis AHP untuk model SCOR level 1 menghasilkan bobot yang dinyatakan dalam nilai eigen ditunjukan pada Tabel 3 . Kemudian, salah satu contoh matriks perbandingan berpasangan untuk pengukuran bobot metrik level 1 untuk atribut kinerja reliabilitas ditunjukan pada Tabel 4. Hasil pehitungan bobot untuk setiap hierarki ditunjukan pada Gambar 3.
Tabel 3 Hasil pengukuran bobot proses bisnis dengan AHP

\begin{tabular}{lccc}
\hline \multicolumn{1}{c}{ Proses Bisnis } & eigen & & \\
\hline Perencanaan & 0,4235 & CI & 0,0773 \\
Pengadaan & 0,0733 & RI & 1,1200 \\
budidaya & 0,2291 & CR & 0,0690 \\
produksi & 0,1496 & & \\
distribusi & 0,1245 & & \\
\hline
\end{tabular}

Keterangan: $\mathrm{CI}=$ indeks konsistensi, $\mathrm{RI}=$ indeks random, $\mathrm{CR}=$ rasio konsistensi.

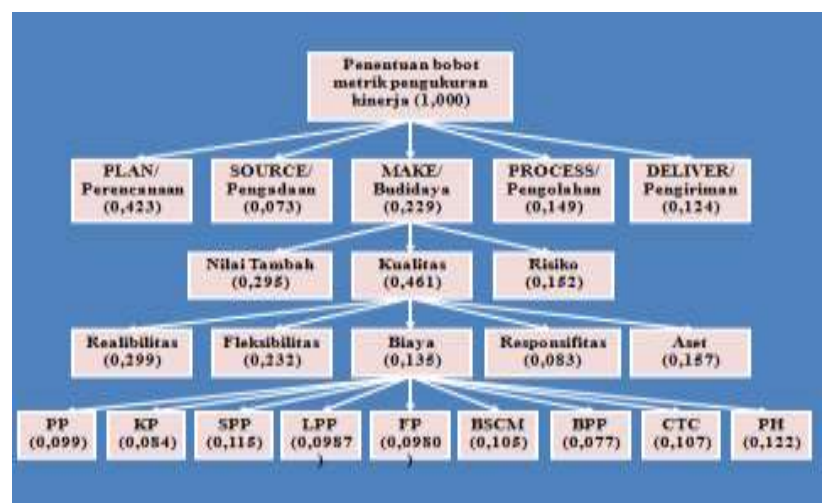

Gambar 3 Hasil AHP

Tabel 4 Perbandingan berpasangan metrik level 1 untuk atribut kinerja reliabilitas

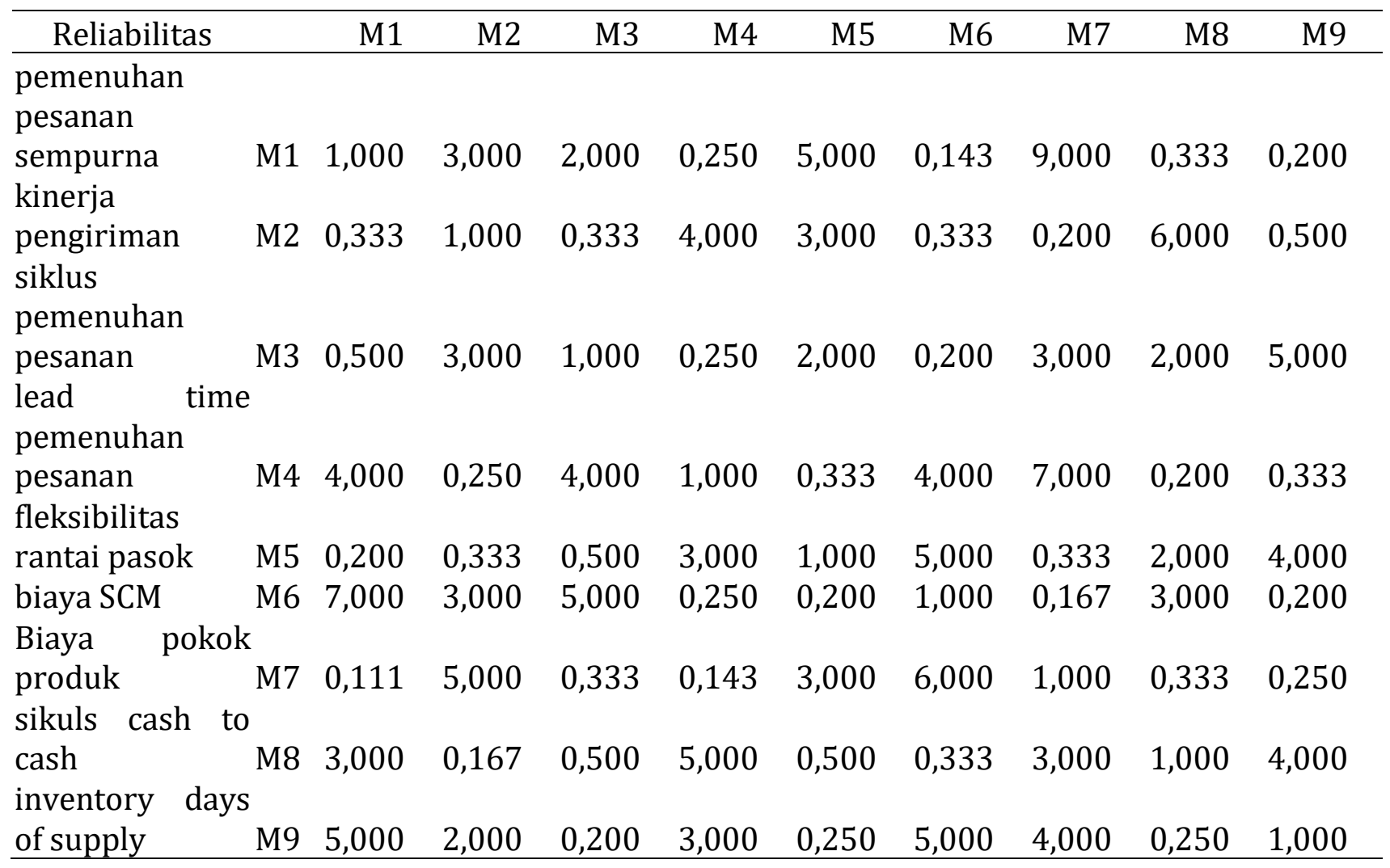

Nilai setiap metrik level diperoleh dari pengukuran beberapa parameter kuantitatif dari rangkaian proses yang terjadi di perusahaan. Metode pengukuran ditunjukkan pada Tabel 5. 
Tabel 5 Teknik pengukuran metrik kinerja

\begin{tabular}{|c|c|}
\hline Metrik kinerja & Cara perhitungan \\
\hline $\begin{array}{l}\text { Pemenuhan } \\
\text { pesanan }(\mathrm{PP}) \\
(0,099)\end{array}$ & $\begin{array}{l}\text { Permintaan konsumen yang dipenuhi dalam waktu dan jumlah yang } \\
\text { sesuai \& full/total pesanan (\%) }\end{array}$ \\
\hline $\begin{array}{l}\text { Kinerja } \\
\text { Pengiriman } \\
(\mathrm{KP})(0,084)\end{array}$ & $\begin{array}{l}\text { Persentase pengiriman pesanan tepat waktu yang sesuai dengan tanggal } \\
\text { pesanan konsumen dan atau tanggal yang diinginkan konsumen }(\%)\end{array}$ \\
\hline $\begin{array}{l}\text { Siklus waktu } \\
\text { pemenuhan } \\
\text { pesanan }(0,155)\end{array}$ & $\begin{array}{l}\text { Siklus waktu yang diperlukan untuk memenuhi pesanan } \\
\text { (source+make+delivery) (hari) }\end{array}$ \\
\hline $\begin{array}{l}\text { Lead time } \\
\text { pemenuhan } \\
\text { pesanan }(0,098)\end{array}$ & $\begin{array}{l}\text { Jumlah hari sejak produk diproduksi/diproses hingga dikirim sampai ke } \\
\text { tangan konsumen (hari) }\end{array}$ \\
\hline Fleksibilitas & Waktu yang dibutuhkan untuk merespon rantai pasokan apabila ada \\
\hline Pemenuhan & pesanan yang tak terduga baik peningkatan atau penurunan pesanan \\
\hline $\begin{array}{l}\text { Pesanan } \quad(\mathrm{FP}) \\
(0,086)\end{array}$ & (hari) \\
\hline Biaya SCM & $\begin{array}{llll}\text { Jumlah } & \text { biaya } & \text { pemenuhan } & \text { pesanan }\end{array}$ \\
\hline$(\mathrm{BSCM})(0,105)$ & (perencanaan+pengadaan+pembuatan+pengiriman) dari total biaya (\%) \\
\hline $\begin{array}{ll}\text { Biaya } & \text { Pokok } \\
\text { Produk } & \text { (BPP) } \\
(0,077) & \end{array}$ & Biaya yang diperlukan untuk memproduksi produk (\%) dari total biaya \\
\hline $\begin{array}{l}\text { Cash-to-cash cycle } \\
\text { time (CTC) (107) }\end{array}$ & $\begin{array}{l}\text { Rata- rata persediaan (per hari) + rata- rata konsumen membayar barang } \\
\text { yang sudah diterima (hari) - rata-rata perusahaan membayar ke pemasok } \\
\text { untuk barang diterima (hari) }\end{array}$ \\
\hline $\begin{array}{l}\text { Persediaan } \\
\text { harian }(0,122)\end{array}$ & Waktu yang dibutuhkan sampai barang dikirim ke pelanggan \\
\hline
\end{tabular}

Hasil pengukuran kinerja rantai pasok perusahaan sebagai benchmark seperti yang produk ikan bandeng beku, dengan ditunjukan pada Tabel 6. membandingkan dengan target internal

Tabel 6 Pengkuran metrik kinerja rantai pasok produk ikan bandeng beku

\begin{tabular}{lrrrrr}
\hline \multicolumn{1}{c}{ Metrik Level 1 } & $\begin{array}{c}\text { Nilai } \\
\text { aktual }\end{array}$ & $\begin{array}{c}\text { Bench- } \\
\text { mark }\end{array}$ & $\begin{array}{c}\text { Normali- } \\
\text { sasi }\end{array}$ & Bobot & \multicolumn{1}{c}{ Nilai } \\
\hline Pemenuhan Pesanan Sempurna (\%) & 63 & 69 & 0,913043 & 0,0999 & 0,091213 \\
Kinerja pengirman (\%) & 73 & 79 & 0,924051 & 0,0846 & 0,078175 \\
Siklus Pemenuhan Pesanan (hari) & 3 & 1 & 0,333 & 0,1151 & 0,038367 \\
Lead time pemenuhan pesanan (hari) & 1 & 1 & 1 & 0,0987 & 0,0987 \\
Fleksibilitas Rantai Pasok (hari) & 2 & 2 & 1 & 0,0980 & 0,098 \\
Biaya SCM (\%) & 17 & 14 & 0,823529 & 0,1053 & 0,086718 \\
Biaya Pokok Produk (\%) & 48 & 44 & 0,916667 & 0,0777 & 0,071225 \\
Siklus Cash-to-Cash (hari) & 15 & 10 & 0,666667 & 0,1072 & 0,071467 \\
Inventory days of supply (hari) & 7 & 4 & 0,571429 & 0,1221 & 0,069771 \\
\hline Nilai Kinerja (\%) & & & & & 70,36 \\
\hline
\end{tabular}

Keterangan: data yang digunakan merupakan data hipotetik

Berdasarkan hasil pengukuran, diketahui bahwa kinerja rantai pasok produk bandeng beku saat ini masih sebesar 70,36 \%, dan sebagian besar masih berada dibawah nilai benchmark. Oleh karenanya diperlukan perbaikan untuk meningkatkan kinerja rantai 
pasok produk ikan bandeng beku. Perbaikan kinerja dilakukan dengan mendefinisikan secara mendetail setiap proses pada level 1 hingga rangkaian proses pada level 3 . Pemetaan setiap level pada rangkaian proses sistem rantai pasok produk ikan bandeng beku ditunjukan pada Gambar 4.

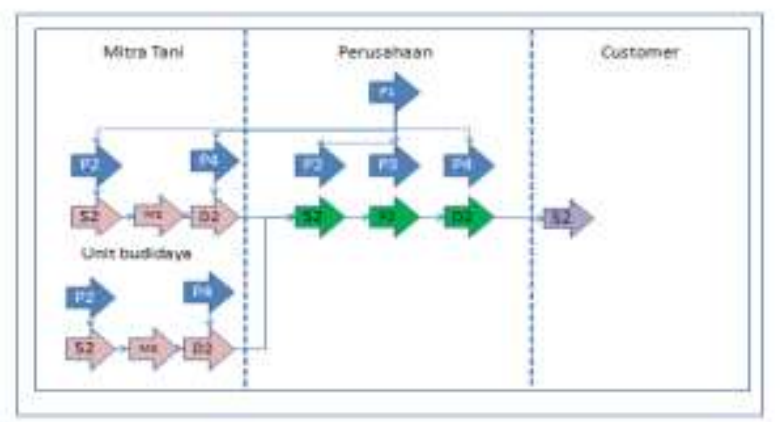

Gambar 4 Desain aliran material pada rangkaian proses di setiap entitas rantai pasok

Keterangan: $\mathrm{P}=$ plan, $\mathrm{S}=$ source, $\mathrm{M}=$ budidaya, $\mathrm{P}=$ processing, $\mathrm{D}=$ delivery

\section{KESIMPULAN DAN IMPLIKASI}

Berdasarkan hasil analisis deskriptif diperoleh 10 metrik level 1 untuk setiap atribut kinerja pada proses pengukuran kinerja rantai pasok produk ikan bandeng beku. Hasil pengukuran kinerja menunjukan bahwa kinerja rantai pasok saat ini baru mencapai 70,36 \% dari target perusahaan, sehingga perlu dilakukan perbaikan mulai dari perencaan para pemasok, perusahaan dan customer.

\section{DAFTAR PUSTAKA}

Kementerian Kelautan dan Perikanan [KKP]. 2011. Kelautan dan Perikanan dalam Angka 2011. Jakarta (ID): KKP.

Badan Pusat Statistik [BPS]. 2013. Perkembangan beberapa indikator utama sosial-ekonomi Indonesia. Jakarta (ID): BPS.

Saputra ID dan Sarjono H. 2014. Pembuktian Penerapan SCOR model versi 10.0 pada perusahaan distributor (PT Surya Perdana Lestari) dengan perusahaan produksi. Jakarta (ID): Binus University.

Marchante AP, Melcon AA, Trebar M, Filippin P. 2014. Advance traceability system in aquaculture supply chain. Food Engineering. 2014;122:99-109.

Marimin dan Magfiroh N. 2010. Aplikasi teknik pengambilan keputusan dalam manajemen rantai pasok. Bogor (ID): IPB Press.

Setiawan A. 2009. Studi peningkatan kinerja manajemen rantai pasok sayuran dataran tinggi terpilih di Jawa Barat [tesis]. Bogor (ID): Institut Pertanian Bogor. 